\title{
Transforming relationship between neopatrimonial state and business for the sustainable development: Cluster Governance model
}

\author{
Viacheslav Maracha ${ }^{1}$ and Sergey Bespalov ${ }^{2, *}$ \\ ${ }^{1}$ Financial University under the Government of the Russian Federation, Department of System \\ Analysis in Economics, Prosp. Leningradsky, 49, 125993 Moscow, Russian Federation \\ ${ }^{2}$ Russian Presidential Academy of National Economy and Public Administration (RANEPA), Prosp. \\ Vernadskogo, 82, bld. 1, 119571, Moscow, Russian Federation
}

\begin{abstract}
Transforming relationship between neopatrimonial state and business in Russia are examined from the perspectives of sustainable development and "networkisation" of the business. We consider it on the basis of the innovation clusters formation as regional collaborative communities, the transition to Cluster Governance model as a new advanced form of the innovation process organisation, and environment factors of this transition. As a factor holding back this transition in Russia, the dominance of the "technocratic" approach to digitalisation of public administration is noted with an underestimation of the environment and human factors and the mechanisms of informal correction of powerbureaucratic decisions. In the context of ensuring the economic development sustainability the following effect is important: reducing cluster governance to traditional management due to the fact that the cluster is transformed into a vertically integrated holding, which is a reduction of the pluralistic and heterogeneous structure to a monistic and homogeneous one. The relevance of these risks to sustainable development of Russia is associated with the neopatrimonial nature of the current model of government with the high role of its informal component. The paper raises the question of measuring the influence of informal relations on the decision-making processes performing by government bodies.
\end{abstract}

\section{Introduction}

Network organisation and systemic principles for transforming relationship between the state and innovative business are examined on the basis of the innovation clusters formation. The focus is on the formation of innovation clusters as regional collaborative communities, the transition to cluster governance as a new advanced form of the innovation process organisation, as well as government policy to support such a transition, along with government and business relations in this context.

* Corresponding author: sbesp@mail.ru 
If we consider clusters not as objects from of some economic theory, but as a new type of governance organisation (i.e., from "organisational point of view"), then this requires a new quality of government, a transition to its modern models [1]. The analysis of the innovation process organisation forms, including cluster ones, is based on the same organisational-theoretical scheme that is used in the typology of models of government: "hierarchies - markets - networks" [2]. The hypothesis is that this scheme can act as a "common denominator" for considering models of public administration, innovative business organisation and interaction of business with the state [1].

\section{Network organisation, systemic principles of governance and socio-cultural factors hindering the transition to cluster governance}

We consider innovation clusters as a special case of the network organisation where the innovation process is based on regional collaborative communities. The concept of "collaboration" personifies the highest, interactive form of cooperation and comes from the word "laboratory", reflecting the nature of relationship that once developed in the laboratories of the American Silicon Valley [3, p. 28]. In the scientific literature, collaboration means the process of formal and informal coordination between autonomous players, during which they create joint rules and organisations to regulate their interactions and activities or solve the tasks that unite them [4]. Moreover, these joint rules are shared by all participants, bringing them mutual winnings, and the coordination itself can occur continuously.

Table 1. The correspondence between type of organisation (and governing), its structure (character of links) and typical institutions.

\begin{tabular}{|c|c|c|}
\hline $\begin{array}{c}\text { Type of organisation / } \\
\text { governing }\end{array}$ & $\begin{array}{c}\text { Structure } \\
\text { (character of links) }\end{array}$ & Typical institutions \\
\hline $\begin{array}{c}\text { Hierarchical / } \\
\begin{array}{c}\text { Control \& } \\
\text { Administration }\end{array}\end{array}$ & $\begin{array}{c}\text { Priority of "vertical" } \\
\text { links }\end{array}$ & $\begin{array}{c}\text { State institutions, } \\
\text { classical universities, } \\
\text { "classical" corporations }\end{array}$ \\
\hline $\begin{array}{c}\text { Market / } \\
\text { Management }\end{array}$ & $\begin{array}{c}\text { Based on "horizontal" } \\
\text { links }\end{array}$ & $\begin{array}{c}\text { "Plain" corporations, } \\
\text { innovation enterprises } \\
\text { (startup companies) }\end{array}$ \\
\hline $\begin{array}{c}\text { Network / } \\
\text { Governance }\end{array}$ & $\begin{array}{c}\text { Links can be described } \\
\text { by a graph of voluntary } \\
\text { form }\end{array}$ & $\begin{array}{c}\text { Innovation clusters and } \\
\text { ecosystems }\end{array}$ \\
\hline
\end{tabular}

For describing the network nature of coordination in collaborative communities we offer the model of "Cluster Governance". This is a specific case of the network organisation when one of network nodes accepts a role of the "kernel" providing the coordinating and infrastructure functions. The relations between the "kernel" and other nodes (elements of the cluster) look like a "vertical" structure, but in fact they are based on a voluntary delegation at the "kernel" of the sovereignty of the cluster elements without being forced. In general, the cluster elements relationship are saved as market and hence, "horizontal". It allows combining the advantages of hierarchical and market organisation forms within the Cluster Governance model [5].

Industrial clusters are market-organised "value chains" that do not necessarily have the organisational specifics of innovation clusters. But this does not mean that innovations in them are not carried out; it's just that the process is organised in them differently. In terms of innovations, they interact on market principles both with startups (units of innovation 
process market organisation) and with large corporations (units of a hierarchical organisation that can "afford" innovation for themselves). Thus, the historical path of cluster formation is a movement from "classical" corporations built hierarchically to "plain" ones, moving to market relations of subcontracting and outsourcing, forming industrial clusters, and further to innovative clusters organised as collaborative networks see table 1 [5].

\section{Three models of public administration and problems of making administrative reforms}

How is the organisational-theoretical scheme "hierarchy - markets - networks" implemented in public administration? Here the network forms correspond to the "publicnetworked" model of New Governance (focusing on participation and partnerships), which in developed countries superimposes on the classic "Weberian" model of rational bureaucracy (which was hierarchical and focused on clear execution of procedures in accordance with the law) and complements its market-oriented model New Public Management (focusing on results) - see table 2.

These three models differ by the systemic principles of governing, which is emphasized by the use of different English-language terms: Control \& Administration (governing implemented in hierarchical structures), Management (corresponds to the market-oriented model) and Governance (corresponds to the public-networked model) [2].

Table 2. The correspondence between types of organisation (and governing) and models of public administration.

\begin{tabular}{|c|c|c|}
\hline $\begin{array}{c}\text { Type of organisation / } \\
\text { governing }\end{array}$ & $\begin{array}{c}\text { The model of Public } \\
\text { Administration }\end{array}$ & Focus of the model \\
\hline $\begin{array}{c}\text { Hierarchical / } \\
\text { Control \& } \\
\text { Administration }\end{array}$ & Rational bureaucracy & Procedure \\
\hline $\begin{array}{c}\text { Market / } \\
\text { Management }\end{array}$ & $\begin{array}{c}\text { New Public Management } \\
\text { (NPM) }\end{array}$ & Result \\
\hline $\begin{array}{c}\text { Network / } \\
\text { Governance }\end{array}$ & New Governance & $\begin{array}{c}\text { Participation and } \\
\text { partnership }\end{array}$ \\
\hline
\end{tabular}

However, in transition countries the introduction of new models of Public Administration took place in the face of unresolved problems from the previous historical stage: for example, the Russian bureaucracy has been burdened by "post-Soviet" problems and "insufficiently rational" in the sense of the Weberian model - struck by the "traditionalism" of informal ties, which is typical for most developing countries, and by personal and clan patronage at the lower and middle levels of the state apparatus (the neopatrimonial type of administration, or neopatrimonialism [6]). These features are typical for the most transition countries [7].

The considered problems had added to the list of historically accumulated internal contradictions of public administration system in transition countries. At the same time, they actualize the difficulties of forming the classical Weberian model that were not solved at the previous stage: the absence of fixed standards in some areas of regulation, the formal "fetishism" of paper work, the weakness and unsystematic implementation of meritocratic principles of selection and promotion of personnel, the lack of clear rules for interaction between different levels and types of government.

So for transition countries it becomes relevant the problem of measuring the influence of informal relations on the decision-making processes performing by government bodies 
("the level of neopatrimonialism"). For example, Rachel Sigman and Staffan Lindberg from the Varieties of Democracy Institute (V-Dem - https://www.v-dem.net/en) use empirical tools to assess the levels of neopatrimonialism in African political regimes [8]. Further we consider the general method of measuring neopatrimonialism.

\section{Measuring neopatrimonialism}

$\mathrm{V}$-Dem project is one of the largest-ever social science research-oriented data collection programs which co-ordinates the network of almost 3000 country experts. The V-Dem indicators (approximately 350 in total) are based on assessments by experts who are situated both within and outside each country. The latest version of the dataset, V10, covers 202 countries from 1789-2019 with annual updates to follow. It is co-hosted by the University of Gothenburg and University of Notre Dame. The V-Dem dataset includes measures of both de jure and de facto aspects of political regimes [9]. Neopatrimonialism includes elements of patrimonial (mostly informal) and rational-bureaucratic rule which coexist and are sometimes interwoven. It implies de facto practices guided by norms or informal rules that differ from those typically associated with the corresponding formal institutions, so the large selection of de facto indicators is very helpful for measuring neopatrimonialism.

For conceptualising neopatrimonialism Sigman and Lindberg apply the model by Bratton and Van de Walle [10] who define a neopatrimonial regime as one that includes clientelism, presidentialism and the use of public resources for private/political benefit (a particular case of the third is corruption). Following this conceptual model, Sigman and Lindberg use indicators from the V-Dem dataset to construct an index of neopatrimonial rule. In addition to an overall index measuring the latent concept of neopatrimonial rule predicted by indicators across these three dimensions, they also produce sub-indices for each of the three dimensions. The sub-indices permit finer-grained analysis to better understand patterns of variation across the three dimensions and how the different dimensions relate to one another. Each of the four indices are derived using a Bayesian factor analysis (BFA) [11] which allows to estimate the latent concepts from the means of the posterior distributions of each of the V-Dem indicators included in each dimension. The overall Neopatrimonialism index uses the BFA technique on the pool of 16 indicators employed in the three sub-indices [9].

These measurements show that the degree of neopatrimonialism in African countries varies vastly within the continent. There is a clear visible difference between countries scoring lowest and highest on the Neopatrimonialism index. The dimensions of neopatrimonialism are also configured variously. For instance, clientelistic regimes tend to also score high on corruption, although there are some exceptions, where moderate levels of political patronage are combined with high corruption. Furthermore, less presidentialistic regimes vary considerably in the extent to which their politics are clientelistic and plagued by corruption.

Sigman and Lindberg adapted the conceptual model of neopatrimonialism by Bratton and Van de Walle for the particular conditions and development context of African countries. We can made a plausible assumption that other groups of countries (Latin American, East Asian, Arab, Post-Soviet, East European, etc.) will require other conceptual models with different dimensions of the Neopatrimonialism index that will be projected otherwise onto the V-Dem dataset. Analysis of Sigman and Lindberg's work allows us to define the generalised method for constructing Neopatrimonialism index, consisting of the following four steps:

1) based on conceptual considerations, a model is constructed with a few key indicators corresponding to the essential characteristics ("dimensions") of the concept; 
2) indicators corresponding to these "dimensions" are disaggregated into a larger number of sub-indices that have a specific empirical relationship within the V-Dem dataset or some other commensurate database;

3 ) the secondary analysis of the data is carried out using suitable mathematical methods, which makes it possible to statistically verify the empirical consistency of the conceptual model;

4) if the consistency of the conceptual model is verified, then we can use its key indicators to measure (quantify) the essential characteristics of neopatrimonialism in the corresponding group of countries.

\section{Factors hindering the transition to the new systemic principles of governance, and the problem of launching institutional transformation mechanisms}

What factors hinder the transition to the new systemic principles of governance? In transition countries elements of the New Governance model (participation and partnership based on the dialogue of stakeholders) are being introduced very poorly due to understandable political and much less frequently analyzed, but more fundamental sociocultural constraints. In general, they can be interpreted as institutional constraints, understanding institutions as complex socio-cultural formations, that is, more widely than it is customary in neo-institutional theory [12].

Socio-cultural constraints impede institutional reforms that allow the transition to more advanced models of government [13]. And this, in turn, inhibits innovative development and, in particular, the formation of clusters. From one hand, state stimulation due to the inadequacy of outdated types of governing turns out to be inefficient. And from the other hand, the transition to the cluster governance "by natural way" is difficult due to the same socio-cultural constraints: vertically integrated holdings for the state and corporate managers are much clearer and "culturally closer" than "uncontrolled" clusters [1].

The pluralism and heterogeneity of the cluster composition implies the communicative nature of the interaction within it. One of the key characteristics of the cluster network, which determines the synergistic effect of clusters, is the informal exchange of information, knowledge and creative ideas [14]. Such an exchange is carried out through communication, which, as empirical studies show, should penetrate to the level of middle management and key specialists of organisations participating in the cluster [5]. Accordingly, cluster governance should have the character of communicative governance.

Reducing cluster governance to traditional management is possible only if the cluster is transformed into a vertically integrated holding, which is a reduction of the pluralistic and heterogeneous structure to a monistic and homogeneous one. This is what often happens with clusters in transition countries (and sometimes even in developed countries, for example, in Italy), reproducing socio-cultural factors of resistance to the transition to new systemic principles of governance, which can be attributed to "organisational culture": the desire of managers to replace network interaction with hierarchical ones, communication by giving orders and instructions, etc. Sustainable reproduction of these factors leads to their institutional consolidation, raising questions about effective mechanisms for institutional transformations and the adoption of best practices for sustainable development ensuring.

Application of ideas about the network organisation implies that not only clusters, but also the state are considered as polysubject. Unfortunately, currently at the federal level, support for clusters has largely become a bureaucratic mechanism, operating with a set of formal criteria. When providing state support, the model of cluster governing (and whether it complies with the principles of cluster governance), the nature of the participants 
interaction, as well as the quality of the innovation environment created during this interaction, is taken into account extremely weakly. At the same time, the Cluster Governance model itself, based on delegation of authority from below, is often replaced by "top-down" administration under the pretext of the need to control financial flows allocated for cluster support (Control \& Administration). In other words, the dominant obsolete model of government creates an inadequate systemic model for governing innovative clusters.

On the other hand, new live / mobile zones periodically appear in our public administration, which is generally rigid and hierarchical. For example, the now popular slogan of the "digital economy" implies the creation of "technological platforms", around which the "ecosystem of providers" should be formed. The same logic of forming collaborative communities works as in the Cluster Governance model, if you look at it not from the point of view of how many "numbers" in the created platforms, software or the Internet - but from the point of view of how control is built (or softer - coordination) by the ecosystem of providers, how communication is organised there, how common (infrastructure) functions are generated, how powers are delegated, etc. The role of the "kernel" for such a cluster is played by the "technological platform", which acts as a common infrastructure for them and sets uniform technical and organisational standards of work. At the same time, service providers, in accordance with the principles of forming collaborative communities, must agree on general "rules of the game" and follow them in their interactions with each other.

Russian examples of innovative ecosystems are the partner ecosystem of service and content providers on the ERA-GLONASS platform, formed within the framework of a project consortium of Russian enterprises based on Non-profit partnership "GLONASS" with the participation of NTI "Autonet" (https://www.rvc.ru/press-service/mediareview/nti/117093), as well as innovative ecosystems created on the basis of the industry unions of the National Technology Initiative (https://2035.dev/en). The main goal of NTI is to promote the development of Russian companies in fundamentally new industry markets, which at the time of the launch of NTI in 2015 did not yet exist, or they were in their infancy. Moreover, in 10-20 years, the volume of each of these future markets should exceed US \$ 100 billion globally. This approach is based on the assumption that Russian companies have a chance to take their rightful place, first of all, in those markets that have not yet been formed.

The combination of such global trends as networkisation and digitalisation leads to the formation of smart cities, which are also regarded as innovative ecosystems "capable of evolution all along its lifecycle..., since a city never dies and must be able to reconfigure itself while its internal and external environment changes... this evolutionary process can't be steered in top down way, either by a supra rational actor or on a self-regulating basis as claimed by the authors of the first order cybernetics" [15]. Basing on the above-mentioned typology of the innovation process organisation forms, we assume that it is smart cities that can become the ideal environment for the formation and development of innovation clusters. The keystone of smart cities is Smart Government, which has three main areas [16]: economic development, a vibrant political life and supporting open innovations. For contemporary complex societies, Elinor and Vincent Ostrom have developed the concept of polycentric governance [17]. It is obvious that polycentric smart governance should provide direct democracy [15] and public participation as well as stakeholder communication mechanisms. 


\section{How to ensure the launch of the institutional transformations mechanisms that create the necessary improvement in the quality of public administration and conditions for sustainable development?}

How to ensure the launch of the institutional transformations mechanisms that create the improvement in the quality of public administration necessary for the successful development of innovative clusters and ecosystems? In the implementation of reforms in countries of catching-up development, the role of "transplantation" of institutions, which is a process of borrowing "good" models and practices in other countries, is important.

In the process of institutional borrowing, 3 stages can be distinguished, at which different groups of factors play a key role (in Russian conditions):

1) making a decision on borrowing;

2) "implantation" of the borrowed institution (with adaptation to local conditions);

3 ) its further development, "rooting", rejection or transformation under the influence of local conditions.

At the 1st and 2nd stages of reform in Russia, the key prerequisite for success is a coalition of representatives of the highest (politicized) bureaucracy in support of the import of the institution, or "package of institutions" (a set of norms and establishments that have historically developed as unified complexes). When deciding on the import of institutions (at the first stage), the role of public and - especially - expert discussions is often very significant (although not decisive).

In the long term (at the 3rd stage), when the institution is "rooted", in addition to economic and political factors, socio-cultural factors (they are largely informal) are extremely significant. Therefore, in order to avoid rejection during the transplantation of institutions, it is necessary not only formalizing them, but also adapting to informal relations reproduced within the framework of already existing institutions and sociocultural practices. With significant cultural differences between the donor and recipient country, the adaptation of institutions can be accompanied by a significant change in the original samples.

Thus, the conditions for the "rooting" of the institution and ensuring its sustainable development, in addition to economic and political factors that represent its "material supports", also include socio-cultural factors that mean the correspondence between the value idea and the "spiritual supports" of the institution [12]. A typical mistake of reformers, according to Victor Polterovich, is that they are trying to immediately introduce the most advanced institutions which do not satisfy the existing restrictions in the given country, either in material support (technological, resource, political, etc.), or in spiritual support (cultural or institutional, that is restrictions from other institutions).

In the latter case, we can talk about the problem of "fitting" new or transplanted institution into the already existing institutional order. This is manifested in political restrictions expressed in the desire of the elite, which occupies key positions within the framework of this system of institutions, to maintain this position in the future. In this sense, the inconsistency of the ideas of the transplanted institutions with the "spiritual supports" of the existing civil culture becomes a completely material (political) limitation of transplantation. As a result of this discrepancy, the transplanted institutions turn out to be dysfunctional: instead of adapting to the existing institutional order and "rooting" in the culture of the recipient country, they are deformed, creating institutional traps that impede further development [18]. 
To avoid such a negative scenario, it is necessary, according to Victor Polterovich, to consider the reform not as a one-step act of "shock therapy" or the adoption of radical laws, but as a "step-by-step" sequence of transformations leading to the ultimate goal. Moreover, each "development step" must satisfy the principle of the "zone of proximal development" by Lev Vygotsky [19]. In the case under consideration, this means that the result of this "step" corresponds to the restrictions, existing in the given country and at the given moment of time, both in the material support and in the spiritual support of the institution.

Elements of the trajectory formed by the sequence of "development steps", with the exception of the initial and final elements, Victor Polterovich calls "intermediate institutions" $[20 ; 18]$. These institutions must not only satisfy existing constraints, but at the same time weaken them, creating favorable conditions for the next steps. The formation of intermediate institutions is a creative and at the same time political process that does not have universal schemes.

\section{Conclusion}

All of the above leads to the conclusion that the process of transition to the network forms of organisation (in particular, to the Cluster Governance model in the organisation of the innovation process and the New Governance model in public administration) is a subject to the general principles of institutional borrowing, "rooting" of institutions and ensuring their sustainable development. The introduction of advanced models and the adoption of best practices require political support and socio-cultural adaptation, during which the initial samples are transformed to adapt them to the environment peculiarities and national "cultural soil". At the same time, "intermediate institutions", which correspond to the principle of the "zone of proximal development", are well established. This makes it possible to overcome organisational resistance that prevents progressive changes and generates risks for the sustainable development of the Russian economy and society. The considered features of transition countries make relevant the problem of measuring neopatrimonialism. For coping it the generalised method of constructing Neopatrimonialism index was offered. In the future, we are going to consider the composition of this index for Post-Soviet countries.

Paper was prepared as a part of the research work within the framework of the Government order for the RANEPA.

\section{References}

1. V.G. Maracha,T.S. Krasnikova, 2017 Relations of the state and business in the context of innovation clusters formation in Russia: typology of models and socio-cultural factors Russia and the world: global challenges and strategies for socio-cultural modernization. Mat. Int. Conf. (Moscow) ed A V Tikhonov (Moscow: FNRSC RAS) 497-502 (2017)

2. S.V. Bespalov, V.G. Maracha, Strategic cycle of public administration in the context of the multimodality principle and the idea of a "viable" state, Public Administration 19, 4 (108), 25-31 (2017)

3. N.V. Smorodinskaya, Network innovation ecosystems and their role in dynamisation of economic growth, Innovation 7 (189), 27-33 (2014)

4. A.M. Thomson, J.L. Perry, Collaboration processes: inside the black box, Public Administration Review 66, 1 (2006) 
5. V. Maracha, T. Krasnikova, The evolution of innovation process organization forms: transfer to collaboration networks and "Cluster Governance" Management of LargeScale System Development (MLSD), 10th Int. Conf. (2017) http://ieeexplore.ieee.org/document/8109660

6. S.N. Eisenstadt, Traditional patrimonialism and modern neopatrimonialism (Beverly Hills, CA: Sage Publications, 1973)

7. D.C. Bach, Patrimonialism and neopatrimonialism: comparative trajectories and readings, Commonwealth \& Comparative Politics 49, 3, 275-94 (2011)

8. R. Sigman, S.I. Lindberg, Neopatrimonialism and democracy: an empirical investigation of Africa's political regimes, Working Paper Series 56 (Gothenburg: VDem Institute, 2017)

9. S. Coppedge et. al., V-Dem Dataset v7.1 Varieties of Democracy (V-Dem) Project (Gothenburg: V-Dem Institute, 2017)

10. M. Bratton, N. van de Walle, Democratic experiments in Africa: regime transitions in comparative perspective (Cambridge: Cambridge University Press, 1997)

11. A.D. Martin, K.M. Quinn, J.H. Park, M.J.H. Park, Package MCMCpack (2017) https://mran.microsoft.com/snapshot/2017081/web/packages/MCMCpack/MCMCpack .pdf

12. V.G. Maracha, 2016 Economics and "general social analysis" from the perspective of system-institutional approach, System Analysis in Economics 1, 339-42 (2016)

13. A.A. Auzan, et al, Socio-cultural factors of innovative development and successful implementation of reforms, Report of the CSR (Moscow, 2017) https://www.csr.ru/ru/publications/sotsiokulturnye-faktory-innovatsionnogo-razvitiyai-uspeshnogo-vnedreniya-institutsionalnyh-preobrazovanij

14. L. van den Berg, E. Braun, W. van Winden, Growth clusters in European cities: an integral approach, Urban Studies 38, 1, 185-205 (2001)

15. C. Rochet, A. Belemlih, Direct democracy as the keystone of smart city governance as a complex system Complex System Design and Management Proc. Int. Conf. CSDM 2016 (Paris) ed G Fanmuy, E Goubault, D Krob, F Stephan (Cham: Springer)

16. C. Rochet, J.D. Pinzón Correa, Urban lifecycle management: a research program for smart government of smart cities, GeSec 7, 2, 1-20 (2016)

17. E. Ostrom, Beyond markets and states: polycentric governance of complex economic systems, Transnational Corporations Review 2 (2), 1-12 (2010)

18. V.M. Polterovich, Elements of the theory of reforms (Moscow: Economics, 2007)

19. L.S. Vygotsky, Thinking and speech ed 5, rev. (Moscow: Publishing house "Labyrinth", 1999)

20. V.M. Polterovich, Transplantation of economic institutions, Economics of Contemporary Russia 3, 24-50 (2001) 